\title{
GCU
}

Glasgow Caledonian

University

University for the Common Good

\section{European leaders unmasked: Covid-19 communication strategy through Twitter}

Drylie-Carey, Lindsey; Sánchez-Castillo, Sebastian; Galán-Cubillo, Esteban

\section{Published in:}

Profesional de la Información

DOI:

10.3145/epi.2020.sep.04

Publication date:

2020

Document Version

Author accepted manuscript

Link to publication in ResearchOnline

Citation for published version (Harvard):

Drylie-Carey, L, Sánchez-Castillo, S \& Galán-Cubillo, E 2020, 'European leaders unmasked: Covid-19 communication strategy through Twitter', Profesional de la Información, vol. 29, no. 5.

https://doi.org/10.3145/epi.2020.sep.04

\section{General rights}

Copyright and moral rights for the publications made accessible in the public portal are retained by the authors and/or other copyright owners and it is a condition of accessing publications that users recognise and abide by the legal requirements associated with these rights.

Take down policy

If you believe that this document breaches copyright please view our takedown policy at https://edshare.gcu.ac.uk/id/eprint/5179 for details of how to contact us. 


\title{
European leaders unmasked. The Covid-19 communication strategy through Twitter feed
}

\begin{abstract}
The coronavirus disease 2020 Covid-19 (SARS-CoV-2) pandemic is exacting a huge toll on individuals, families, communities, and societies across the world. The study of public communication is a key aspect for slowing the spread of the virus and therefore reducing the death rate. This article analyses political leaders' crisis communication during the Covid-19 pandemic of the most affected European countries, Boris Johnson (United Kingdom), Emmanuel Macron (France), Pedro Sánchez (Spain) and Giuseppe Conte (Italy), in addition to Tedros Adhanom as representative of the World Health organisation (WHO) and Ursula Von der Leyen President of the European Union (EU). The study focuses on the visual information (images and videos) published in their Twitter profiles, with the aim of highlighting the strategies of the health authorities recommendations during the first 40 days of the pandemic. After analysis of the visual content of 634 tweets, the results show significant differences amongst the preventative measures recommended (social distancing, use of masks, hand washing, etc.) and the public image projected by the leaders in their Twitter profiles.
\end{abstract}

\section{Key words}

Crisis communication; Covid-19; Pandemic; Twitter; Audiovisual communication; Authoritative leadership; Political Communication

\section{Introduction}

Since the Covid-19 pandemic has expanded globally, public health institutions, nonprofit organisations and governments have reacted by providing precise information to the population about the illness (Lipsitch; Swerdlow; Finelli, 2020; Thelwall; Thelwall, 2020), with the intention of successfully arresting the virus responsible for hundreds of thousands of deaths globally. Previous sanitary crises such as H5N1 (1997), N1H1 (2009), SARS (2002), MERS (2012), H7N9 Chinese (2013) or the Ebolavirus (2014), showed that social networks and mobile technologies exerted an essential role in the diffusion of information and were decisive elements of the public health strategies (Wise, 2001; Tirkkonen; Luoma-aho, 2011; Liu; Kim, 2011). The containment success of any type of public health crisis depends, to a large extent, on the effective communication of the risk factors and measures of protection. The World Health Organisation (WHO), has an obvious focus on the importance of communication which achieves maximum results in terms of healthy behavioural 
change, whilst minimising risk. In concrete, the WHO indicates that social communication is decisive in the pursuit to convince populations of adopting measures that can avoid risks during sanitary crises (Parks; Lloyd, 2004) and is a tool for controlling pandemic bursts (Brennan; Gutiérrez, 2011).

Sanitary crises are exceptional situations which produce uncertainties on a grand scale, negative emotions such as fear, distrust and anger can form strong barriers to an effective communication strategy (Guidry et al., 2017). The Perception of Risks model developed by various authors (Covello et al., 2001; Baron et al., 2000; Fischhoff, 1989; Chess et al., 1995; Glik, 2007; Caims et al.,2013) explains the processes concerned with disseminating information related to risk, how it affects perceptions related to citizenship and how to take the decisions related to risk. Thus, confidence in the information is key in the formation of risk perception, which could potentially lead to ineffectiveness depending on recommendations and sanitary guidelines (Covello et al., 2001; Guidry et al., 2017; Reynolds, 2009). At times, the perception of confidence or distrust emphasises the lack of agreement exhibited by the experts and leaders (Guidry et al., 2017). Research suggests that the reputation of an institution or leader has a strong influence on public confidence (Coombs; Holladay, 2002; Renn; Levine, 1991; Palenchar; Heath, 2007).

Social networks have transformed the mode in which organisations and leaders communicate with their stakeholders enabling an effective and direct dialogue (McAllister-Spooner, 2009; Sommerfeldt et al., 2012; Kata, 2010). Social Media presents a huge opportunity for involving citizenship in political decisions (Dubois; Gaffney, 2014; Agre, 2002; Dahlgren, 2005; Hindman, 2009; Dubois; Dutton, 2012), as leaders use their visibility in the online world to spread messages (Rogers, 2010; Katz; Lazarsfeld, 1955; Bakshy et al., 2011; Watts; Dodds, 2007). This interactivity is an underpinning contributor to the importance of social networks to the field of risk communication (Alhabash; McAlister, 2014; Bortree; Seltzer, 2009; Lovejoy et al., 2012). In addition, using visual archives, videos, photographs and graphics, can significantly increase the understanding of the phenomena in comparison to only using textual information (Covello, 2003; Houts et al., 2006).

With regards to crisis communication, in concrete, Twitter has been the object of investigation on different occasions (Coombs, 2012; Utz et al., 2012; Veil et al., 2011; Simon et al., 2014; Hagen et al., 2017; Hornmoen et al., 2018). Various studies have indicated an increasing use of social networks, especially Twitter, in this context, due to its accessibility and immediacy. Its capacity to augment the diffusion of information during a crisis, whilst linking the users with sources of critical information in real time, is a fundamental consideration for public health managers and political agents (Hughes; Palen, 2012; Latonero; Shklovski, 2011). The authorities can monitor and offer direct responses to users' concerns (McInnes; Hornmoen, 2018). The activity in the networks can allow authorities to reduce citizen anxiety, inform, detect peaks at an early stage and minimise virus propagation (Bernardo et al., 2013; Aramaki et al., 
2011; Lamb et al., 2013; Paul; Dredze, 2011). In conclusion, Twitter offers a horizontal communication environment which contrasts with the traditional vertical structures prevalent in the communication of an emergency situation (Schultz et al., 2011; Coobms, 2012; Utz et al., 2012; Veil et al., 2011).

\section{The influence of image in politics}

It is well known that images can play a critical role when members of the public are evaluating politicians. Specifically, voters are looking for determined qualities in political leaders (Bailenson, 2008; Lalancette; Raynauld, 2019). Images play a key role in the interpretation of a message for many reasons. Images are perceived as the best tool to effectively present information that is relevant in a political debate (Birdsell, 2007). Visual communication has always been a key aspect of political communication. However, in the last two decades, its importance has increased. Audiovisual media such as television (in multiple screens and with an infinite range of topics, channels and levels of interactivity) has become the principal source for receiving information for a large part of citizenship. Political leaders are aware of the importance of visuals and they study carefully the strategy to build an effective image of themselves through audiovisual resources. Visual imaging plays a central role in constructing political leadership (Schill, 2012). Despite the importance images hold within political communication, their value has not been extensively researched until now with some exceptions (Barnhurst; Quinn, 2012; Filimonov et al., 2016; Powell et al., 2015; Schill, 2012). Images are gaining importance in political discourse and are replacing narrative. Images have been a central component of political communication, especially since the onset of television, but their role has increased exponentially in the last 20 years through the development of the Web and Social Media Platforms (Filimonov et al., 2016). In spite of this, text has not been discarded and particular scholarly studies are detecting that the use of texts, titles and additional information alongside the images can improve the impact of the publication (Muñoz; Towner, 2017).

The President of the United States, Donald Trump, during his visit to Ford factory in May 2020, declared that he did not want to give the pleasure to the press of seeing him in a face mask. His reputation as an eccentric President leads many of us to think that what differentiates him from other political leaders is his capacity for communicating directly without filtering the information. Trump's declaration shows to which extent the decision to wear or not a mask in public has been a function of the leader's communication strategy. In short, although the rest of the leaders can follow a similar strategy (in this case calculating the convenience of wearing masks) they are not conscious of this. Through the analysis of their public communications it can be determined how carefully they manage to avoid specifically referring to the health crisis. Characteristically using a Minister or Aide for delivering data relating to levels of contagion and deaths and Experts for giving advice about social distancing or the use of masks. 


\section{Authentic leadership}

Authentic leadership has a supporting role in the extent to which government has credibility and is therefore even more vital during the unfolding of a pandemic situation such as Covid-19 (Stander et al., 2015). This research has enabled the drawing of conclusions relating to the level of authentic leadership displayed by the respective European leaders involved in the pandemic. In their review of the literature relating to authenticity and authentic leadership (Gardner et al., 2011) suggest that the development of the construct can be summed up by four principal dimensions; selfunderstanding, objective appreciation and recognition of personal limitations, personal actions and interpersonal relationships.

The notion of authentic leadership is further underpinned by a raft of theoretical foundations, including morality, emotional intelligence, personal values, leadership per se and well-being (Walumbwa et al., 2010) amongst others. For this research it is vital to drill down to the particular area of authenticity which underpins the context, i.e. the political arena. Authentic leadership has been examined widely including within the areas of education (Nordhal, 2009), religion (Edwards; Kim, 2019) and within the context of the armed forces (Tucker, 2012). However, the examination of the construct within the political agenda is less widespread. There are some studies concerned with personality traits and leadership styles (Pittinsky; Tyson, 2005; Paramova, 2014) and political skill (Douglas; Ferris; Perrewe, 2005) but in comparison to the context of education and organizational development, this is an area where authentic leadership and by extension, authentic authority has been neglected. This may be a representation of the evolution of the current profile of the political role in itself where, to enter the political sphere, implies the acceptance of personal scrutiny and of allegiance to a viewpoint which is not always a true representation of closely held personal views. What has emerged, through the extant research from disparate contexts, are particular characteristics and trends which are universal to authentic leadership.

Levels of engagement, presentational aspects and symbols are used to analyse Twitter visual communications (images and videos) during the initial 40 days of the Covid-19 pandemic as a determination of the authenticity of leadership for the specific European leaders this research is concerned with in order to draw conclusions about their communication strategies for coping with the greatest global crisis since II World War. 


\section{Method}

The research design was to examine how the European leaders responsible for the countries most affected by Covid-19 planned their crisis communication on Twitter, from March 14 to April 22, 2020. To this end, uploaded audiovisual files from the Twitter profiles have been analyzed $(M=3.35$, $D T=1.657)$ for Emmanuel Macron (@EmmanuelMacron), Boris Johnson (@BorisJohnson), Pedro Sánchez (@sanchezcastejon), Tedros Adhanom (@DrTedros), Giuseppe Conte (@GiuseppeContelT) and Ursula von der Leyen (@vonderleyen). The selection took into account the highest incidence of the Covid-19 pandemic during the period, Italy $(24,648$ deaths), Spain $(21,717)$, France $(20,796)$ and the United Kingdom $(17,337)$. Countries that represent $78.63 \%$ of the total of those who died on that date in Europe $(107,453)$. A total of 634 tweets with audiovisual content were retained, with a distribution by leaders, France $(n=89,14 \%)$, United Kingdom $(n=102,16.1 \%)$, Spain $(n=187,29.5 \%)$, Italy $(n=32,5 \%)$, WHO $(n=95,15 \%)$, EU $(129,20.3 \%)$.

The codebook with the variables under study was constructed from a dual perspective, deductive and inductive. First, a list of variables was created using the deductive method according to the intent of the investigation. Subsequently, inductively, after an exhaustive content analysis of all the variables, those that were not pertinent, present or redundant, were eliminated, including some that were initially ignored. Finally, a code book with 9 complex variables emerged. The first 6 variables are multiple in nature, thus ensuring the multiplicity of options to define a given audiovisual file:

1. "Themes Discussed". Includes 23 items, (WHO, Measures of confinement and coordination of those; WHO, Diagnostic testing; WHO, Improvement concern of public health; Vaccine development or achievement; Future economic situation or damage- measures adopted; Death toll; Number of people who have tested positive; Recognition or thanks to health professionals; Recognition or thanks to security forces, police, army; Recognition or thanks to general public; Recognition or thanks to others; Practices to combat virus; Confinement; Hand washing; Social distancing; Mask wearing; Working at home practices; Consultation or meetings with other political leaders; National press; International press; Home politics; Mention of own physical or mental state; Mention of own or personal family situation).

2. "Typology of image or video". Is constructed with 12 items, (Video; Infographic video; Image; Infographic image; Includes a title; Supplemental textual information; Institutionally led declaration; Declaration or interview from a different source or media; Personal/familiar video or Selfie; Video or image from a Covid-19 informational or marketing campaign; Content from television; Content from social networks).

3. "Mise en scene". Is constructed with 11 items, (Standing; Seated; Use of a table or lectern; Appears alone; Appears with more people around; How many other people in video/image (not including the leader); Office; Press Room; Street; Other locations; Does not appear). 
4. "Mention of other international leaders". With 14 items, (Emmanuel Macron; Boris Johnson; Giuseppe Conte; Pedro Sánchez; Angela Merkel; Donald Trump; Justin Trudeau; António Costa; Mark Rutte; Xi Jinping; Shinzō Abe; Tedros Adhanom Ghebreyesus; Ursula Von der Leyen; Does not refer to any other leader).

5. "Mention of other international countries or institutions". 14 items, (United Kingdom; Germany; France; Italy; USA; Japan; China; Canada; Nordic countries; Spain; European Union; WHO; Other countries; Does not refer to any other country).

6. "Descriptive data", 6 items, (Duration of the video; Number of images per post; Number of views; Number of comments; Number of shares; Number of likes).

The remaining 3 dichotomous variables respond to a (yes / no) option if they are relevant or present in the image; "Wearing a mask" (M=1.66, $D T=0.982)$, "Hashtag" $(M=0.75, D T=0.431)$, "War time language" $(M=0.21, D T=0.410)$. Both the variables with multiple responses and the dichotomous variables have been subjected to a descriptive process using hypothesis testing, Pearson's bivariate (Rx-y) and an Anova analysis of variance. The statistical procedure was performed with SPPS_IBM v.26.0.0.

\section{Results}

First, the analysis of the data obtained after coding the variables shows that all the variables respond to a significant correlation with the different leaders considered, "Themes discussed" ( $\alpha .73)$; $\left[X^{2}(110, N=634)=346.758, p<.000\right]$, "Typology of image or video" ( $\alpha .79)$; [ $\left.X^{2}(55, N=634)=228.454, p<.000\right]$, "Mise en scene" ( $\alpha$. $69) ;\left[X^{2}(5, N=634)=198.567, p<.000\right]$, "Mention of other international leaders" $(\alpha$ .74), $\left[X^{2}(65, N=634)=362.181, p<.000\right]$, "Mention of other international countries or institutions" ( $\alpha .65) ;\left[X^{2}(55, N=634)=294.121, p<.000\right]$, "Descriptive data" $(\alpha .70)$; $\left[X^{2}(25, N=634)=388.091, p<.000\right]$.

Regarding dichotomous variables, "Wearing of the mask" $X^{2}(15, N=634)=245.087$, $\mathrm{p}<.000 ; \quad\left(\mathrm{rf}=.622, \mathrm{p}<.000\right.$; Cramérs $\vee .359 \mathrm{p}<.000$; Eta-squared $\left.\left(\eta^{2}\right) .294\right)$, "Hashtag" $X^{2}(5, N=634)=78.164, p<.000$ ( $r f=.351, p<.000$; Cramérs V .351 p $<.000$; Eta-squared $\left.\left(\eta^{2}\right) .214\right)$ y "Wartime language" $X^{2}(5, N=634)=242.164, p<$ $.000\left(\mathrm{rf}=.619, \mathrm{p}<.000\right.$; Cramérs $\mathrm{V} .619 \mathrm{p}<.000$; Eta-squared $\left.\left(\eta^{2}\right) .577\right)$. These data show that leaders have used visual resources on Twitter in a significantly different way, far from a joint communication strategy of the WHO recommendations and the proposals of the different national health officials.

\subsection{Leadership, engagement and authenticity}

There are four areas of engagement which are pertinent in the discussion related to the enhancement of leadership and authenticity which can be determined from the analysis of visual Tweets. The typology (or source) of the image or video itself which 
can be specific to social media (ie a selfie or a re-posting) or intended for a different audience (institutional or televisual declaration), the duration of a video if it is used within a tweet, the actual total number of tweets over the prescribed period and the responses (indicated through comments, shares and likes) generated by the posts.

Tweet typology, in other words, the use of specific material adapted for the medium, leads to a greater perceived sense of attention and authority by the social media audience as it not only creates a fit for purpose communication, but one which has an intentional receivership. The examination of the data which indicates the highest usage of specific material (indicated by a personal video or selfie or re-tweets of content from social networks provided in the table below (sum of $1^{\text {st }}$ and $2^{\text {nd }}$ variables in Table 1 as a \% of total tweets) in this way during the prescribed period comes from Ursula von der Leyen (with 25\% of tweets from these sources), Emmanuel Macron (with 19\% from specific sources), and Boris Johnson (with 15\%).

Table 1. Measures of Engagement relating to authoritative leadership (By the authors)

\begin{tabular}{lcccccc}
\hline & $\begin{array}{c}\text { Boris } \\
\text { Johnson }\end{array}$ & $\begin{array}{c}\text { Emmanuel } \\
\text { Macron }\end{array}$ & $\begin{array}{c}\text { Pedro } \\
\text { Sánchez }\end{array}$ & $\begin{array}{c}\text { Giuseppe } \\
\text { Conte }\end{array}$ & $\begin{array}{c}\text { Von der } \\
\text { Leyen }\end{array}$ & $\begin{array}{c}\text { Tedros } \\
\text { Adhanom }\end{array}$ \\
\hline Personal/familiar video or Selfie & $11(10.7)$ & $18(20.2)$ & $4(2.1)$ & 0 & $31(24)$ & $8(8.4)$ \\
Content from social networks & $19(18.6)$ & $16(17.9)$ & $5(2.6)$ & 0 & $36(30)$ & $12(12.6)$ \\
Number of comments (mean) & 2563 & 869 & 566 & 4113 & 175 & 523 \\
Number of shares (mean) & 4263 & 8501 & 799 & 4790 & 401 & 983 \\
Number of likes (mean) & 17539 & 8629 & 4249 & 7173 & 1061 & 2728 \\
Likes/followers (index) & 0.66 & 0.14 & 0.59 & 0.32 & 0.42 & 0.21 \\
\hline$\quad$ Total tweets & 102 & 89 & 187 & 32 & 129 & 95 \\
\hline $\mathrm{n}(\%)$ & & & & & &
\end{tabular}

As an extension of this, there is an argument to say that the greater the transparency relating to informational communications which leaders can use at a time of crisis, the better, and thus, the more truthful they appear. However, authentic leadership is also concerned with understanding and vision (Luthans; Avolio, 2003) and the demonstration of the understanding of the medium which they are using to communicate is a clear indication of audience recognition and desire for engagement on their terms. Although it is significant to point out that communication advisors could have been and probably were involved - although during a crisis this may not be as prominent an issue as the reactive mode in which the leaders find themselves is less controlled and lest we overlook the relationship which Donald Trump has with his unfiltered Twitter feed and the complete lack of control his advisors have in this area (Gray, 2019) - this is still a noteworthy indication of commitment to clear communication. As is the duration (or playtime) of posted videos. The duration of videos posted on a Twitter feed can also indicate the level of understanding and engagement the leaders have with the medium and translate their desire for functional communication. It is this understanding related to the achievement of functional 
communication which links into the attainment or otherwise of authoritative leadership. A short video, in a Twitter feed enables bite-sized information to be shared and is better assimilated by the receiving audience. Table 2 indicates clearly that Emmanuel Macron and Ursula von der Leyen achieve the shortest means of video time posted (2min50 and $2 \min 36$ respectively).

Table 2. Themes discussed

\begin{tabular}{lccccccc}
\hline \multicolumn{1}{c}{ (By the authors) } \\
& Boris & Emmanuel & Pedro & Giuseppe & Von der & Tedros & $p$ \\
Johnson & Macron & Sánchez & Conte & Leyen & Adhanom & \\
\hline WHO recommendations & $2(1.9)$ & $30(33.7)$ & $42(22.4)$ & $17(53.1)$ & $50(38.7)$ & $43(45.2)$ & .001 \\
Confinement & $38(37.2)$ & $26(29.2)$ & $20(10.6)$ & $8(25)$ & $3(2.3)$ & $6(6.3)$ & .004 \\
Hand washing & $7(6.8)$ & $1(1.1)$ & $9(4.8)$ & $3(9.3)$ & $1(0.7)$ & $1(1)$ & .017 \\
Social distancing & $14(13.7)$ & $3(3.3)$ & $6(3.2)$ & $3(9.3)$ & $1(0.7)$ & 0 & .001 \\
Mask wearing & $7(6.8)$ & $8(8.9)$ & $5(2.6)$ & $3(9.3)$ & $9(6.9)$ & $5(5.2)$ & .278 \\
\hline \multicolumn{1}{c}{ Total tweets } & 102 & 89 & 187 & 32 & 129 & 95 & \\
\hline \multicolumn{10}{c}{$(\%)$} & \multicolumn{7}{c}{}
\end{tabular}

Partner (2020) in her article relating to communicating effectively with Twitter during a crisis adds another variable which supports leadership in this context which is related to the number of tweets which are dispensed at this time. She contends that during watershed moments engagers (those members of the population who engage with social media and in particular Twitter) are avid for information and that effective communication rules which usually indicate that a distillation of information into a reduced number of Tweets is preferable are amended to indicate that a high number of Tweets actually gives an indication of a more reassuring strategy. This can be verified in the data with the trend analysis of the number of Tweets per day over the 40 day period for the leaders, $\left[X^{2}(140, N=634)=973.475, p<.000\right]$, (Figure 1$)$.

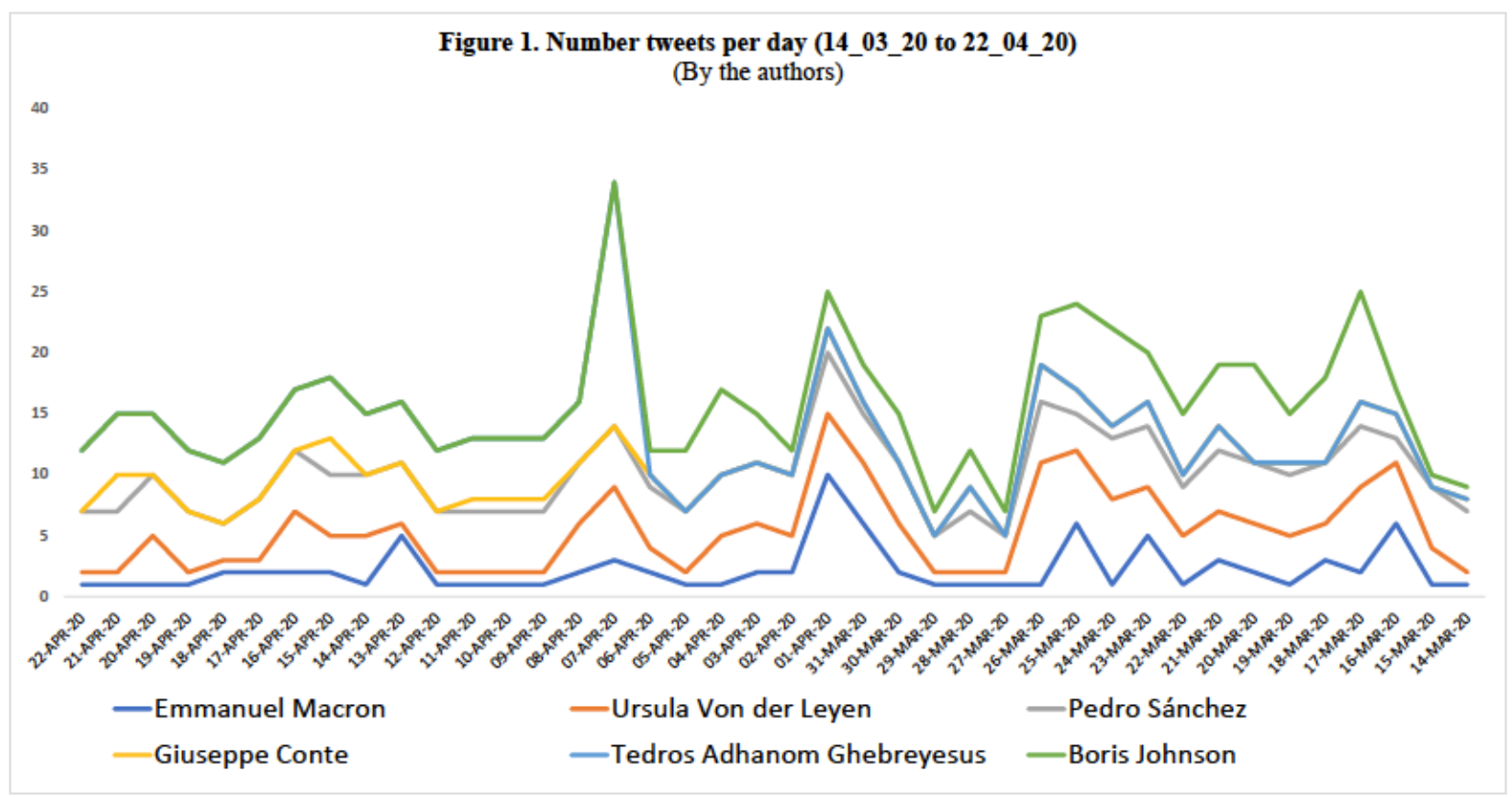


The contrast in approach is noteworthy: Giuseppe Conte and Pedro Sánchez remain regular in the number of tweets shared per day throughout the 40 days with Giuseppe Conte sharing the least number of tweets overall at 32 over the full period; Boris Johnson shows a constant high output of Tweets until 6th April 2020 (the day after he was admitted to hospital with Covid-19 symptoms); it is difficult to comment on this aspect of tweet history for Tedros Adhanom as the tweet history before 7th April 2020 is not available, leaving Emmanuel Macron and Ursula von der Leyen as the two leaders who overall tweet regularly with specific spikes in their tweet practice mainly related on the one hand, with Emmanuel Macron's prime time addresses to the nation and economic re-launch (12th March, 16th March, 1st April, 9th April and 13th April) and on the other with Ursula von der Leyen's addresses to the European parliament and joint press conferences (17th March, 24th March, 26th March and 7th April).

Finally, the most obvious measures related to the level of engagement with social media instances are related to the opportunities for two-way interaction from engagers which, in the Twitter context, are represented by the number of comments, shares and likes that the posts receive. Although this number, in terms of comments and shares, does not indicate a positive response (as, of course, the comment or intent of the share can carry a positive or negative connotation), it still purports engagement. In terms of approval, which clearly supports the notion of authentic leadership the number of likes indicates a positive level of support. Table 1 indicates that Boris Johnson achieves by far the highest number of positive responses from followers (0.66 index).

\subsection{Presentational aspects of the leaders}

The data related with the curation (mise en scene) of the tweeted image or video (in other words the way in which the scene is presented or set up) can support or detract from authentic leadership. Avolio and Gardner (2005), and Baker (2020) posited that a strong relational representation fosters openness and trust in followers and indeed introduces the concept of authentic 'followership'. Images where there is a representation of the leader with more people around them in an obvious leadership position (i.e. in a situational context such as an office, a press room or even in a more public arena such as the street) supports the image of a strong leader with their acquiescent followers.

The leaders who presented themselves in this context with the highest regularity were Emmanuel Macron and Ursula von der Leyen. However, this could also represent a counter-intuitive situation with the particular characteristics of the Covid-19 pandemic as one of the principle measures related to the practices put in place to combat the virus refers to social distancing. In the detailed examination of the images/video, social distancing measures are not always being followed as can be seen in the image below. Notions of 'acting by example' are clearly overlooked in this instance of social distancing which is further verified when reflecting on the number of times the leaders appear whilst wearing a mask (one of the prescribed measures to combat the spread 
of the virus). The presentational aspects highlighted here (lack of social distancing in photo below) refute the notion of the achievement of authentic leadership by the studied leaders during the Covid-19 pandemic crisis (see image 1).
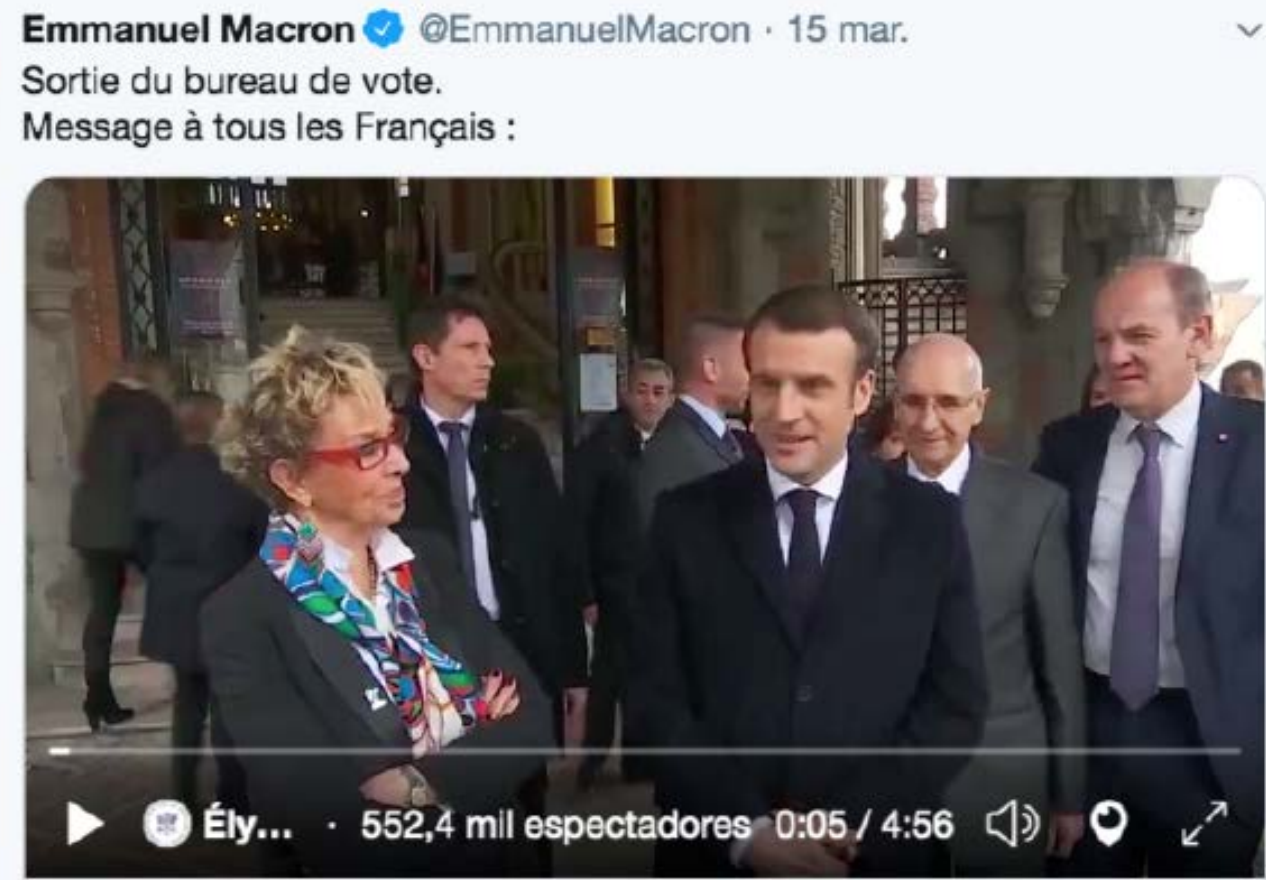

\section{Élysée @Elysee}

Sortie du bureau de vote. Message à tous les Français $\mathcal{P}$ pscp.tv

๑ $959 \quad$ † $959 \quad \bigcirc 4,2 \mathrm{mil} \quad \uparrow$

Image 1. Screen shot from Emmanuel Macron's. Source: Twitter

Related to the impact and effectiveness of the communication there are different parameters that can be used to measure the impact of a tweet (Hanna; Rohm; Crittendem, 2011) such as comments, likes-count, number of followers, shares or hashtags. However, as it is political leaders which are the focus of the study, it has already been mentioned above that the more comments received in a post does not necessarily mean that the level of engagement was higher. Indeed, during the Covid19 emergency most of the user interactions were criticisms of crisis decisions. The same can be applied if the number of shares are considered because in many cases the users share a tweet (re-tweet) with comments and interpretations that are not favourable to the leader. So, after analysing the material and taking into account previous research (Arora et al., 2019), we have used the following calculation (likes/followers $=$ index) for measuring the effectiveness of the communication of the leaders. A high number of followers can presume that the communication that the leader is going to use in the platform is more adapted to the requirements and the consumption habits of the users. Looking at the leader communications, there are two 
patterns that can be directly related with the impact level of the message. Although the contrary could be assumed, as far as leader communication strategy is involved, there is a correlation between the number of message publications and the level of their success (measured in likes per number of followers). The results show that a high number of publications result in an impact on the messages (Table 1).

The second pattern that has been identified is the use of selfies or personal videos, photos or amateur material specially developed for the platform. In as much as it is the person who is directly communicating through their profile, the more proximity shown by the leader, the more impact is achieved. Putting together those variables, the leader who has achieved the most impact related with his number of followers is Boris Johnson as he is able to combine the introduction of personal images and selfies with a number of tweets (usually not more than 5 or 6 per day) that provides his followers the possibility to start a conversation and share. Thus, they become an important cog in the process of public debate construction (Table 1).

From this research we have many insights to suggest that the strategy of communication of the leaders is not transparent. The leaders almost never quote in their tweets topics that are key to the pandemic management such as vaccines for Covid-19, the number of deaths or the number of new cases. The WHO organisation is not highly quoted by the leaders (Table 2). This could be explained by the fact that the director of the WHO organisation is facing many accusations relating to the hiding of information and strangely, all his tweets before 7th April are no longer available. Additionally, the director of the WHO dedicates many of his tweets to discussions with other leaders such as Donald Trump and in defence of his own decisions rather than for giving advice or clear guidelines for facing the pandemic.

When Tedros Adhanom provides valuable information, it is often diluted amongst a vast number of tweets (some days more than 50 ). This enables countries, when they quote the WHO recommendations, to use a variety of sources depending on the day, the tweet, the video, document or conference that they are using. Some weeks Tedros Adhanom posts more than 300 tweets and some of them are more reminiscent of an Instagram influencer (quoting celebrities and introducing concepts such as 'Love' and 'Peace', etc... without providing any context) than a director of a global medical organisation facing the worst health crisis in the last decades.

The lack of transparency by avoiding key aspects of the health crisis is supported by the use of the images that the leaders post. In their tweets they very rarely refer to any key aspects for controlling the contagion such as hands washing, social distancing and wearing masks. In almost all the cases investigated, the number of references to those topics represents less than $10 \%$ of their publications (Table 2). However, it is in the representation of their leader profile that it can be determined that they are far from offering themselves to their citizens as leading by example in order to cope with the pandemic. They do not appear wearing masks, washing their hands or practicing 
social distancing due, in part, to the fact that they present themselves alone in almost all of the cases. Moreover, they do not show themselves in confinement as they principally share images portraying their working day in the office or announcing the latest measures from the Press Room. Uniquely, Boris Johnson shows himself from confinement (see image 2 below) perhaps because he was diagnosed with Covid-19 and put into isolation until he was hospitalized.

Boris Johnson \#StayAlert (2)BorisJohnson - 1 abr.

Here's an update to bring you up to speed on some of the things that we are doing to protect our NHS.

We will beat coronavirus together by staying at home, protecting our NHS and saving lives.

\#StayHomeSaveLives

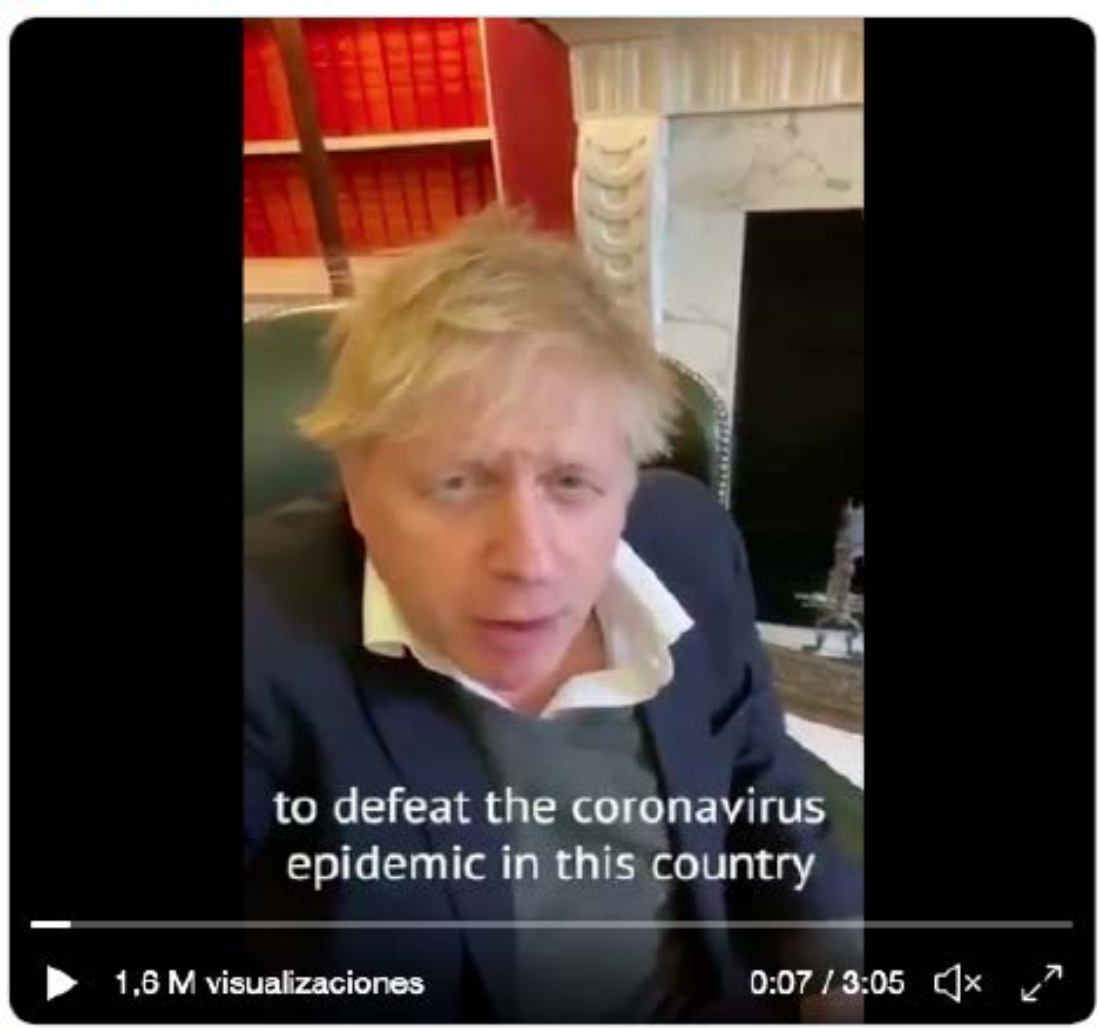
$6,4 \mathrm{mill}$
†๖ $4,8 \mathrm{mi}$
( $25,8 \mathrm{mil}$
$\uparrow$

Image 2. Screenshot from Boris Johnson's feed. Source: Twitter

Analysing the pictures that leaders have been sharing during the first 40 days of pandemic, we can conclude that they are working mostly alone (they do not appear regularly engaged in the decision making process with other collaborators or experts apart from Ursula von der Leyen), without wearing a mask. Additionally, they do not take the opportunity of their influential position for reinforcing (by doing it themselves) habits such as social distancing (see Emmanuel Macron's image 1 shown above), wearing gloves or hand washing before or after a meeting (Table 3 ). 
Table 3. Curation of image or video

\begin{tabular}{|c|c|c|c|c|c|c|c|}
\hline & $\begin{array}{c}\text { Boris } \\
\text { Johnson }\end{array}$ & $\begin{array}{c}\text { Emmanuel } \\
\text { Macron }\end{array}$ & $\begin{array}{c}\text { Pedro } \\
\text { Sánchez }\end{array}$ & $\begin{array}{c}\text { Giuseppe } \\
\text { Conte }\end{array}$ & $\begin{array}{l}\text { Von der } \\
\text { Leyen }\end{array}$ & $\begin{array}{c}\text { Tedros } \\
\text { Adhanom }\end{array}$ & $p$ \\
\hline Mask wearing appearances & 0 & 0 & $4(2.3)$ & 0 & 0 & 0 & .000 \\
\hline Leaders appears with other people & $9(8.8)$ & $16(17.9)$ & $13(6.9)$ & $4(12.5)$ & $35(27.1)$ & $4(4.2)$ & .000 \\
\hline office & $8(7.8)$ & $13(14.6)$ & $6(3.2)$ & $11(34.3)$ & $23(17.8)$ & $4(4.2)$ & .001 \\
\hline Total tweets & 102 & 89 & 187 & 32 & 129 & 95 & \\
\hline
\end{tabular}

Related with the adaptation of communications to social media consumption habits, many of the leaders post the full content of press conferences for example and do not make the effort of extracting the main headlines to publish them separately in a more appropriate bite sized portion. To publish the whole content could be perceived as a bid for transparency but, as discussed in a previous section of this article, in terms of optimum communication strategy, it is more appropriate to adapt the content to the requirements of the platform. Some leaders, such as Boris Johnson and Emmanuel Macron, are able to combine their approach where they post the whole intervention in addition to some extracts which they offer as pertinent guidelines for popular consumption. This is why we have taken into account the duration of the videos including the percentage of videos of less than 3 minutes (Table 4).

Table 4. Typology of image or video (By the authors)

\begin{tabular}{lccccccc}
\hline & $\begin{array}{c}\text { Boris } \\
\text { Johnson }\end{array}$ & $\begin{array}{c}\text { Emmanuel } \\
\text { Macron }\end{array}$ & $\begin{array}{c}\text { Pedro } \\
\text { Sánchez }\end{array}$ & $\begin{array}{c}\text { Giuseppe } \\
\text { Conte }\end{array}$ & $\begin{array}{c}\text { Von der } \\
\text { Leyen }\end{array}$ & $\begin{array}{c}\text { Tedros } \\
\text { Adhanom }\end{array}$ & $p$ \\
\hline Leader appearance & $31(30.3)$ & $34(38.2)$ & $168(89.8)$ & $29(90.6)$ & $117(90.6)$ & $39(41.0)$ & .001 \\
Including Hashtags & $72(70.5)$ & $39(43.8)$ & $157(83.9)$ & $25(78.1)$ & $119(92.2)$ & $66(69.4)$ & .001 \\
Including title & $24(23.5)$ & $3(3.3)$ & $31(16.5)$ & 0 & 0 & $12(12.6)$ & .000 \\
Infographic image & $30(29.4)$ & $1(1.1)$ & $9(4.8)$ & 0 & 0 & $11(11.5)$ & .001 \\
Visual accompaniment & $62(60.7)$ & $81(91)$ & $178(95.1)$ & $31(96.8)$ & $119(92.1)$ & $75(73.6)$ & .000 \\
Images & $17(16.6)$ & $32(35.9)$ & $12(6.4)$ & $14(43.7)$ & $41(31.7)$ & $28(29.4)$ & .000 \\
Videos & $45(44.1)$ & $49(55)$ & $166(88.7)$ & $17(53.1)$ & $78(60.4)$ & $47(44.2)$ & .001 \\
Videos <180 seconds & $19(42.2)$ & $40(81.6)$ & $45(27.1)$ & $12(66.6)$ & $60(76.9)$ & $31(65.9)$ & .002 \\
Video duration (mean) & 33.19 & 2.50 & 49.49 & 3.33 & 2.36 & 80.50 & \\
\hline \multicolumn{1}{c}{ Total tweets } & 102 & 89 & 187 & 32 & 129 & 95 &. \\
\hline \multicolumn{7}{c}{} \\
\hline
\end{tabular}
$\mathrm{n}(\%)$

It is clear that the leaders are aware of the importance of using images (videos and photos) for illustrating the messages that they are wanting to distribute in their publications (Table 4). In addition, the leaders also make use of infographic resources to present the information in a more digestible and attractive way. They are also aware of the usefulness of hashtags and titles for the videos and photos which they regularly add to facilitate the tagging of the content. 


\section{Discussion}

The aim of this research is to examine how the European leaders whose countries were the worst hit by the virus, made use of Twitter in the health crisis. Our analysis demonstrates some clear differences between the leaders of Italy, Spain, UK and France. Using Twitter strategically in relation to the dissemination of vital recommendations from the World Health Organisation helps to combat the spread of the virus and ultimately save lives as previous research has demonstrated when applied to previous outbreaks. Although, the leaders acknowledged the importance of providing information to the public through social media and using visuals re-enforce the message, most of them did not realise the importance of being transparent (i.e. not avoiding the key topics of the crisis) and developing audiovisual material specifically targeted for the platform. The different styles of leadership are reflected in their published messages. Their profiles are constructed as an institutional medium for information and do not personalise the content for engaging citizens. Following the analysis of the data, the leaders do not use the scope of social media messaging to full capacity (i.e. showing their personal respect of confinement measures such as practising social distancing or appearing in videos and/or images wearing a mask). This lack of proximity is particularly significant whilst coping with a sanitary crisis. It is to be taken into consideration that social media's dialogical character presents challenges to leaders as this is the first time in recent history when they are confronted with losing their traditional vertical position of communication. Nevertheless, the leaders have mostly opted to maintain their communication strategy using a top down (vertical) approach by utilising the microblogging platform mainly as a news service with very little interest in entering into a two-way dialogue with the users. In the main, Twitter has been used for reproducing contents developed for other purposes (television, marketing campaigns, newspapers etc.). This can be justified due to the unprecedented situation faced with the Covid-19 health crisis and the consequences of applying unproven, novel strategies, which could cause irreparable damage in terms of their leadership profile. As described above, authoritative leadership emanates from understanding the medium; having precise, clear communications which have been adapted for the situation and its purpose and distilling the information at the appropriate rate. None of the leaders managed to attain the criteria consistently during this crisis, with some managing better in some areas than others. However, the first 40 days of a crisis situation can be considered as fundamental for the positive outcome and future developments for the health of a nation including the long term economic situation and the managing of information at this time is vital. The higher the authentic authority of the leader in times of crisis, the easier it is to impose necessary actions and sanctions. It seems that the leaders we investigated in this research were not able to portray an adequate level of authentic authority within their communication strategy as defined by their use of Twitter.

One specific example of this lies in the potential positive use of interactive communication and is it is evident that social media is an interpersonal communication 
medium which falls into this bracket if used correctly (Veil; Buehner; Palenchar, 2011) and the capacity to listen stands a key part of the communication process which the leaders poorly availed themselves of. In spite of this lack of adaptation the real value of any message is in the quality of the content. In this aspect, as far as the leaders managed to offer up to date content, properly tagged and labelled (for ease of retrieval) they were successful in their purpose. From a user/follower perspective, they appeared as a reliable, current and informed source of information without filter (in favour or against them).

During the Ebola virus in 2014, Twitter was a key element in the response to the crisis by the authorities, both to reassure the public and to offer advice on how to avoid and combat infection (McInnes; Hornmoen, 2018). Although the incidence of Ebola virus outside Central Africa was limited, the then Director of the World Health Organization (WHO), Margaret Chan commented, "In my long career in public health management, I have never seen a health crisis that produce so much fear and terror, beyond the affected countries" (Chan, 2014). The study by Chew and Eysenbach (2010) concluded that during the H1N1 outbreak in 2009, Twitter provided a valuable source of opinions and experiences that could be used in real time to analyse the thoughts and attitudes of those concerned and allowed health and political authorities to better respond to citizens' concerns.

The media coverage of the Covid-19 has turned out to be far superior to other scenarios related to previous health crises. According to Ducharme (2020), the number of articles published on Covid-19 multiplied by 23 compared to the publications on the Ebola virus in 2018. Twitter is the most frequently used social network by $97 \%$ of the 193 member states of the UN, according to a study by Twiplomacy (Lüfkens, 2019) followed by Facebook. Video content and social media usage has increased 33\% during the Covid-19 crisis, and the hegemony of political communication online during the Covid-19 health crisis is centered on Twitter. The profiles of the leaders considered for this research continue to add followers; Emmanuel Macron (5.2 M), Boris Johnson (2.7 Million), Pedro Sánchez (1.3 M), Tedros Adhanom (1.2 M), Giuseppe Conte $(700,000)$ and Ursula von der Leyen $(320,000)$.

There are several considerations about this article that should be taken into account, which should not be treated as limitations, but rather as an incentive to continue this research. First, the study focused on Twitter, so future efforts in the study of communication on the Covid-19 should consider other social networks such as Facebook and Instagram with which to build a more robust scientific field related to communication within a pandemic context. Expanding the scope will certainly improve the validity of statistical data. Secondly, it is considered very opportune to transfer the methodology and the codebook to the entire chronological extent of the pandemic, with the intention of confirming the data obtained in the present investigation. 


\section{Conclusions}

Therefore, Twitter can be considered as a relevant channel for communication with the target audience during epidemic outbreaks and other health emergencies. By ensuring effective and responsible messages, politicians have the capacity to play their leadership role in the present and future global health challenges.

The results of this research are broadly considered to be contained within the following findings:

1. The analysis of the specific leaders' Twitter activity reveals non-consistency in the response to face a global challenge on a European or even global scale. Europe has not been able to act in coordination and the economy has been the main focus of the message's content of the European Commission President. It seems that the past denomination of the European Union (European Economic Union) is still strongly present within the ethos of the organisation.

2. The leader of the WHO does not portray the legitimacy or transparency through to lead the global effort that is required to confront a world health crisis. All tweets before 7th April from the Tedros Adhanom profile have been deleted and he has dedicated most of his posts to arguing with other leaders and to justify previous decisions.

3. The leaders are aware of the importance of the use of the visual image to build leadership and to use it as a principle source of communication. Nevertheless, there is a clear gap between the content of their tweets and the personal actions or values that are transmitted through the pictures and videos they post. They did not take advantage of their influential position to show themselves wearing masks, observing social distancing or following rigorous measures such as regular handwashing. This precluded the citizen's capacity to identify themselves with their leader into the sometimes draconian confinement situation which the leaders themselves had imposed.

4. The profuse use of audiovisual material does not imply that it has always been properly customised for the platform. They limited their opportunities to share institutional pictures or press conference videos. They showed themselves as unfamiliar with the necessity to empathise with their citizens by taking the opportunity of showing themselves in selfies or through audiovisual amateur material.

5. The study is not able to find a clear correlation between the audiovisual discourse and the impact of the content. The duration of the videos, the utilisation of images, or the use of selfies or personal content does not guarantee the level of impact resultant from their publications.

6. Finally, we propose the notion of authentic leadership as a key concept related to the success of a communication strategy in times of crisis. The leaders have not been able to consistently achieve measures of authoritative leadership through the analysis of the images they published in their Twitter feeds. They 
have had varying success in terms of positive levels of engagement and support from the population during this time. Crucially, they did not take the opportunity of 'leading by example' which is a prime component of authenticity. The saying "do as I say not as I do" could legitimately be considered a leitmotiv for the communications strategy of the leadership we investigated in this 40 day, vital, initial period of the unprecedented Covid-19 2020 health pandemic.

\section{References}

Agre, Philip (2002). "Real-time politics: The Internet and the political process". The information society, v. 18, n. 5, pp. 311-331.

https://doi.org/10.1080/01972240290075174

Alhabash, Saleem; McAlister, Anna (2014). "Redefining virality in less broad strokes: Predicting viral behavioral intentions from motivations and uses of Facebook and Twitter". New Media \& Society, v. 17, n. 8, pp. 1317-1339.

https://doi.org/10.1177/1461444814523726

Aramaki, Eiji; Sachiko Maskawa; Mizuki Morita (2011). "Twitter catches the flu: detecting influenza epidemics using Twitter". Proceedings of the 2011 Conference on Empirical Methods in Natural Language Processing, pp. 1568-1576. Association for Computational Linguistics.

http://www.aclweb.org/anthology/D11-1145

Arora, Anuja; Bansal, Shivam; Kandpal, Chandrashekhar; Aswani, Reema; Dwivedi, Yogesh (2019). "Measuring social media influencer index-insights from facebook, Twitter and Instagram". Journal of Retailing and Consumer Services, v. 49, pp. 86-101.

https://doi.org/10.1016/j.jretconser.2019.03.012

Avolio, Bruce; Gardner, William (2005). "Authentic leadership development: Getting to the root of positive forms of leadership". The leadership quarterly, v.16, n.3, pp. 315338.

https://doi.org/10.1016/j.leaqua.2005.03.001

Bailenson, Jeremy; lyengar, Shanto; Yee, Nick; Collins, Nathan (2008). "Facial similarity between voters and candidates causes social influence". Public Opinion Quarterly, v. 72, pp. 935-961.

https://doi.org/10.1093/poq/nfn064

Baker, Nevra (2020). "Authentic Leadership, Leader Optimism, and Follower Affective Commitment: An Experimental Study". Leadership Styles, Innovation, and Social Entrepreneurship in the Era of Digitalization, pp. 329-344. IGI Global. 
Bakshy, Eytan; Hofman, Jake; Mason, Winter; Watts, Duncan (2011). "Everyone's an influencer: quantifying influence on twitter". In Proceedings of the fourth ACM International conference on Web search and data mining, pp. 65-74.

https://doi.org/10.1145/1935826.1935845

Barnhurst, Kevin; Quinn, Kelly (2012). "Political visions: Visual studies in political communication". In Semetko, Holli; Scammell, Margaret (Eds.), The Sage handbook of political communication, pp. 276-291. Thousand Oaks, CA: Sage.

Baron, Jonathan; Hershey, John; Kunreuther, Howard (2000). "Determinants of priority for risk reduction: The role of worry". Risk Analysis, v. 20, n.4, pp. 413-428. https://doi.org/10.1111/0272-4332.204041

Bernardo, Theresa Marie; Andrijana Rajic; lan Young; Katie Robiadek, Mai T. Pham; Julie A. Funk (2013). "Scoping review on search queries and social media for disease surveillance: a chronology of innovation". Journal of medical Internet research, v. 15, n.7: e147.

https://doi.org/10.2196/jmir.2740

Birdsell, David; Groarke, Leo (2007). "Outlines of a theory of visual argument". Argumentation and Advocacy, v. 43, pp. 103-113.

https://doi.org/10.1080/00028533.2007.11821666

Bortree, Denise; Seltzer, Trent (2009). "Dialogic strategies and outcomes: An analysis of environmental advocacy groups' Facebook profiles". Public Relations Review, v. 35, n.3, pp. 317-319.

http://dx.doi.org/10.1016/j.pubrev.2009.05.002

Brennan, Bryna; Gutiérrez, Vilma. (2011). Guía para elaborar la estrategia de comunicación de riesgos. OPS/OMS. Washington, DC, EEUU.

http://www.msal.gob.ar/images/stories/ryc/graficos/0000000750cnt-2014-

04_estrategia-comunicacion-riesgo.pdf

Cairns, Georgina; de Andrade, Marisa; MacDonald, Laura (2013). "Reputation, relationships, risk communication, and the role of trust in the prevention and control of communicable disease: A review". Journal of Health Communication, v.18, n.12, pp. 1550-1565.

https://doi.org/10.1080/10810730.2013.840696 
Chan, Margaret (2014). "WHO Director-General's speech to the Regional Committee for the Western Pacific", 13 October 2014.http://who.int/dg/speeches/2014/regionalcommittee-western-pacific/en/

Chess, Caron; Salomone, Kandice; Hance, Billie; Saville, Alex (1995). "Results of a national symposium on risk communication: Next steps for government agencies". Risk Analysis, v.15, n.2, pp. 115-125.

https://doi.org/10.1111/j.1539-6924.1995.tb00306.x

Chew, Cynthia; Eysenbach, Gunther (2010). "Pandemics in the Age of Twitter: Content Analysis of Tweets during the 2009 H1N1 Outbreak." PLos One, v. 5, n. 12: e14118.

https://doi.org/10.1371/journal.pone.0014118

Coombs, Timothy; Holladay, Sherry (2002). "Helping crisis managers protect reputational assets: Initial tests of the situational crisis communication theory". Management Communication Quarterly, v. 16, n.2, pp. 165-186.

https://doi.org/10.1177/089331802237233

Coombs, Timothy (2012). Ongoing Crisis Communication. Los Angeles. Sage. ISBN: 9781452261362

Covello, Vicent (2003). "Best practices in public health risk and crisis communication". Journal of Health Communication, v. 8, n. 1, pp. 5-8.

https://doi.org/10.1080/713851971

Covello, Vicent; Peters, Richard; Wojtecki, Joseph; Hyde, Richard (2001). "Risk communication, the West Nile virus epidemic, and bioterrorism: Responding to the commnication challenges posed by the intentional or unintentional release of a pathogen in an urban setting". Journal of Urban Health, v. 78, n. 2, pp. 382-391. https://doi.org/10.1093/jurban/78.2.382

Dahlgren, Peter (2005). "The internet, public spheres, and political communication: Dispersion and deliberation". Political Communication, v. 22, n. 2, pp. 147-162. https://doi.org/10.1080/10584600590933160

Douglas, Ceasar; Ferris, Gerald; Perrewe, Pamela (2005). "Leader political skill and authentic leadership". Authentic leadership: Origins, development, and effects, v. 3, pp. 139-154.

Dubois, Elizabeth; Dutton, William (2012). "The fifth estate in internet governance: Collective accountability of a Canadian policy initiative". Revue Francaise d'Etudes Americaines, v. 131, n. 1, pp. 81-97.

https://doi.org/10.3917/rfea.134.0081 
Dubois, Elizabeth; Gaffney, Devin (2014). "The multiple facets of influence: Identifying political influentials and opinion leaders on Twitter". American Behavioral Scientist, v. 58, n.10, pp. 1260-1277.

https://doi.org/10.1177/0002764214527088

Ducharme, Jamie (2020). "News coverage of coronavirus in 2020 is very different than it was for Ebola in 2018". Time, 7 February.

https://time.com/5779872/coronavirus-ebola-news-coverage/

Edwards, Korie; Kim, Rebecca (2019). "Estranged pioneers: The case of African American and Asian American multiracial church pastors". Sociology of Religion, v.80, n.4, pp. 456-477.

https://doi.org/10.1093/socrel/sry059

Filimonov, Kirill; Russmann, Uta; Svensson, Jakob (2016). "Picturing the party: Instagram and party campaigning in the 2014 Swedish elections". Social Media + Society, v.2, n. 3. pp.1-11.

https://doi.org/10.1177/2056305116662179

Fischhoff, Baruch (1989). Helping the public make health risk decisions Effective risk communication, pp. 111-116: Springer, Boston, MA.

https://doi.org/10.1007/978-1-4613-1569-8

Gardner, William; Cogliser, Claudia; Davis, Kelly; Dickens, Matthew (2011). "Authentic leadership: A review of the literature and research agenda". The leadership quarterly, v. 22, n.6, pp.1120-1145.

https://doi.org/10.1016/j.leaqua.2011.09.007

Glik, Deborah (2007). "Risk communication for public health emergencies". Annual Review of Public Health, v. 28, pp. 33-54.

https://doi.org/10.1146/annurev.publhealth.28.021406.144123

Gray, Lucy Anna (2019). What has Trump tweeted today? The latest Twitter posts from the US President and what they really mean. Thursday 14 February.

https://www.independent.co.uk/news/world/americas/us-politics/trump-twitter-todaytweets-latest-update-live-fact-check-explained-a8732821.html

Guidry, Jeanine; Jin, Yan; Orr, Caroline; Messner, Marcus; Meganck, Shana (2017). "Ebola on Instagram and Twitter: How health organizations address the health crisis in their social media engagement". Public relations review, v. 43, n.3, pp. 477486.

https://doi.org/10.1016/j.pubrev.2017.04.009 
Hagen, Loni; Thomas Keller; Stephen Neely; Nic DePaula; Claudia RobertCooperman (2017). "Crisis communications in the age of social media: A network analysis of Zika-related tweets". Social Science Computer Review, v. 36, n. 5, pp. 523541.

https://doi.org/10.1177/0894439317721985

Hanna, Richard; Rohm, Andrew; Crittenden, Victoria (2011). "We're all connected: The power of the social media ecosystem". Business horizons, v. 54, n.3, pp. 265-273 https://doi.org/10.1016/j.bushor.2011.01.007

Hindman, Matthew (2009). The myth of digital democracy. Princeton, NJ: Princeton University Press. ISBN:9780691137612

Hornmoen, Harald; Klas Backholm; Elsebeth Frey; Rune Ottosen; Gudrun Reimerth; Steen Steensen (2018). "Key Communicators perspectives on the use of social media in risk and crises". In Robin Andersen and Purnaka L. de Silva (Eds.) (pp. 439-449). The Routledge companion to media and humanitarian action. New York and London: Routledge, Taylor \& Francis Group.

https://hdl.handle.net/10642/7421

Houts, Peter; Doak, Cecilia; Doak, Leonard; Loscalzo, Matthew (2006). "The role of pictures in improving health communication: A review of research on attention, comprehension, recall, and adherence". Patient Education and Counseling, v. 61, n.2, pp. 173-190.

https://doi.org/10.1016/j.pec.2005.05.004

Hughes, Amanda; Leysia Palen (2012). "The evolving role of the public information officer: An examination of social media in emergency management". Journal of Homeland Security and Emergency Management, v.9.

Kata, Anna (2010). "A postmodern Pandora's box: Anti-vaccination misinformation on the Internet". Vaccine, v. 28, pp. 1709-1716.

https://doi.org/10.1016/j.vaccine.2009.12.022

Katz, Elihu; Lazarsfeld, Paul (1955). Personal Influence: The Part Played by People in the Flow of Mass Communications: a Report of the Bureau of Applied Social Research, Columbia University. Free Press.ISBN:1412805074

Lalancette, Mireille; Raynauld, Vincent (2019). "The power of political image: Justin Trudeau, Instagram, and celebrity politics". American Behavioral Scientist, v. 63, n. 7, pp. 888-924.

https://doi.org/10.1177/0002764217744838 
Lamb, Alex; Michael J. Paul; Mark Dredze (2013). "Separating Fact from Fear: Tracking Flu Infections on Twitter". Conference of the North American Chapter of the Association for Computational Linguistics. Human Language Technologies, pp. 789795.

https://www.aclweb.org/anthology/N13-1097.pdf

Latonero, Mark; Irinia Shklovski (2011). "Emergency management, Twitter, and social media evangelism". International Journal of Information Systems for Crisis Response and Management, v. 3, n.4, pp. 1-16.

https://doi.org/10.4018/jiscrm.2011100101

Lipsitch, Marc; Swerdlow, David; Finelli, Lyn (2020). "Defining the epidemiology of Covid-19 - studies needed". New England journal of medicine, n. 382, pp. 1194-1196. https://doi.org/10.1056/NEJMp2002125

Liu, Brooke; Kim, Sora (2011). "How organizations framed the 2009 H1N1 pandemic via social media and traditional media: Implications for U.S. health communicators". Public Relations Review, v. 37, pp. 233-244.

https://doi.org/10.1016/j.pubrev.2011.03.005

Lovejoy, Kristen; Waters, Richard; Saxton, Gregory (2012). "Engaging stakeholders through Twitter: How nonprofit organizations are getting more out of 140 characters or less". Public Relations Review, v. 38, n. 2, pp. 313-318.

http://dx.doi.org/10.1016/j.pubrev.2012.01.005

Lüfkens, Matthias (2019). Twiplomacy Study.

https://twiplomacy.com/blog/twiplomacy-study-2018/

Luthans, Fred; Avolio, Bruce (2003). "Authentic leadership development”. Positive organizational scholarship, pp. 241, 258. EBSCO : eBook Collection (EBSCOhost).

McAllister-Spooner, Sheila (2009). "Fulfilling the dialogic promise: A ten-year reflective survey on dialogic Internet principles". Public Relations Review, v. 35, n.3, pp. 320-322.

https://doi.org/10.1016/j.pubrev.2009.03.008

McInnes, Colin John; Hornmoen, Harald (2018). "Add Twitter and Stir': The Use of Twitter by Public Authorities in Norway and UK during the 2014-15 Ebola outbreak". Observatorio $\left(\mathrm{OBS}^{\star}\right)$, v. 12, n. 2, pp. 23-46.

Muñoz, Caroline; Towner, Terri (2017). "The image is the message: Instagram marketing and the 2016 presidential primary season". Journal of political marketing, v. 16, n. 3-4, pp. 290-318.

https://doi.org/10.1080/15377857.2017.1334254 
Nordahl, Kristina (2009). Authentic authority: The heart of effective teaching. Laerarutbildningen, Sweden: Malmoe Hoegskola.

http://hdl.handle.net/2043/8450

Palenchar, Michael; Heath, Robert (2007). "Strategic risk communication: Adding value to society". Public Relations Review, v. 33, pp. 120-129.

https://doi.org/10.1016/j.pubrev.2006.11.014

Paramova, Petia (2014). Cultural variations of the personalities, leadership styles and prototypes of political leaders. A comparison of politicians, organisational leaders and voters (Doctoral dissertation, Goldsmiths, University of London).

Parks, Will; Lloyd, Linda (2004). Planificación de la movilización y comunicación social para la prevención y el control del dengue: guía paso a paso (No. WHO/CDS/WMC/2004.2). Ginebra: Organización Mundial de la Salud. ISBN: 9241591072

Partner, India (2020). "Twitter has some tips for journalists and media organisations to communicate effectively amid crisis". Advertising \& Media Insider. Apr. 22, 2020.

Paul, Michael; Mark Dredze (2011). "You Are What You Tweet: Analyzing Twitter for Public Health". In Proc. of the 5th International AAAl Conference on Weblogs and Social Media (ICWSM), pp. 265-272

https://www.aaai.org/ocs/index.php/ICWSM/ICWSM11/paper/viewPaper/2880

Pittinsky, Todd; Tyson, Christopher (2005). "Leader authenticity markers: Findings from a study of perceptions of African American political leaders. Authentic leadership theory and practice: Origins, effects and development, v. 3, pp. 155-182.

https://dx.doi.org/10.2139/ssrn.630605

Powell, Thomas; Boomgaarden, Hajo; De Swert, Knut; de Vreese, Claes (2015). "A clearer picture: The contribution of visuals and text to framing effects". Journal of Communication, v. 65, pp. 997-1017.

https://doi.org/10.1111/jcom.12184

Renn, Ortwin; Levine, Debra (1991). Credibility and trust in risk communication. In R. E. Kasperson, \& J. Stallen (Eds.). Communicating risks to the public (pp. 175217). The Hague: Klewer.

https://link.springer.com/chapter/10.1007/978-94-009-1952-5_10

Reynolds, Barbara (2009). "Building trust through social media. CDC's experience during the H1N1 influenza response". Marketing Health Services, v.30, n.2, pp. 1821. 
https://europepmc.org/article/med/20550001

Rogers, Everett (2010). Diffusion of innovations (4th ed.). New York, NY: Free Press. ISBN: 0029266718

Schultz, Friederike; Sonja Utz; Anja Göritz (2011). "Is the medium the message? Perceptions of and reactions to crisis communication via twitter, blogs and traditional media." Public Relations Review v. 37, pp. 20-27.

https://doi.org/10.1016/j.pubrev.2010.12.001

Schill, Dan (2012). "The visual image and the political image: A review of visual communication research in the field of political communication". Review of Communication, v. 12, pp. 118-142.

https://doi.org/10.1080/15358593.2011.653504

Simon, Tomer; Avishay Goldberg; Limor Aharonson-Daniel; Dmitry Leykin; Bruria Adini (2014). "Twitter in the cross fire- the use of social media in the Westgate mall terror attack in Kenya". PLOS One, v. 9, pp. 1-11.

https://doi.org/10.1371/journal.pone.0104136

Sommerfeldt, Erich; Kent, Michael; Taylor, Maureen (2012). "Activist practitioner perspectives of website public relations: Why aren't activist websites fulfilling the dialogic promise?" Public Relations Review, v. 38, n.2, pp. 303-312.

https://doi.org/10.1016/j.pubrev.2012.01.001

Stander, Frederick; De Beer, Leon; Stander, Marius (2015). "Authentic leadership as a source of optimism, trust in the organisation and work engagement in the public health care sector". SA Journal of Human Resource Management, v. 13, n. 1, pp. 112.

https://dx.doi.org/10.4102/sajhrm.v13i1.675

Thelwall, Mike; Thelwall, Saheeda (2020). "Covid-19 tweeting in English: Gender differences". El profesional de la información, v. 29, n. 3.

https://arxiv.org/abs/2003.11090v1

Tirkkonen, Päivi; Luoma-aho, Vilma (2011). "Online authority communication during an epidemic: a Finnish example". Public Relations Review, v. 37, pp. 172-174.

https://doi.org/10.1016/j.pubrev.2011.01.004

Tucker, William (2012). Relationship between Authentic Leadership Traits and Developmental Education Methods of Air Force Field Grade Officers. Walden University. UMI Number: 3518517 
Utz, Sonja; Friederike Schultz; Sandra Glocka (2012). Crisis communication online: How medium, crisis type and emotions affected public reactions in the Fukushima Daiichi nuclear disaster. Public relations review, v. 39, n. 1, pp. 40-46.

https://doi.org/10.1016/j.pubrev.2012.09.010

Veil Shari; Tara Buehner; Michael J. Palenchar (2011). "A Work-In-Progress Literature Review: Incorporating Social Media in Risk and Crisis Communication". Journal of Contingencies and Crisis Management, v. 19, pp. 110-122.

https://doi.org/10.1111/j.1468-5973.2011.00639.x

Walumbwa, Fred; Wang, Peng; Wang, Hui; Schaubroeck, John; Avolio, Bruce (2010). "Psychological processes linking authentic leadership to follower behaviors". The Leadership Quarterly, v. 21, pp. 901-914.

https://psycnet.apa.org/doi/10.1016/j.leaqua.2014.07.004

Watts, Duncan; Dodds, Peter (2007). "Influentials, networks, and public opinion formation". Journal of consumer research, v. 34, n. 4, pp. 441-458.

https://doi.org/10.1086/518527

Wise, Kurt (2001). "Opportunities for public relations research in public health". Public Relations Review, v. 27, pp. 475-487.

https://doi.org/10.1016/S0363-8111(01)00102-3 